\title{
AKSESIBILITAS DIFABEL PADA OBJEK WISATA MALIOBORO
}

\author{
Fahmi Rafika Perdana \\ Fakultas Ilmu Sosial dan Politik, Sosiologi, Universitas Widya Mataram \\ rafikagunawan354@gmail.com
}

\begin{abstract}
Abstrak
Sebagai warga negara, semestinya difabel memiliki hak yang sama dalam aksesibilitas ruang publik, termasuk pada obyek wisata Malioboro Kota Yogyakarta. Selama ini fasilitas untuk pengunjung difabel masih sangat minim. Kajian ini bertujuan untuk menunjang kebijakan pembangunan kota untuk menjadi "Kota Wisata Ramah Difabel". Penelitian ini menggunakan pendekatan desktiptif kualitatif, dengan menggunakan teknik observasi, wawancara, dokumentasi, dan survey. Penelitian ini merumuskan masalah untuk mengetahui aksesibilitas difabel pada obyek wisata Malioboro. Hasil dari studi menunjukkan obyek wisata Malioboro belum aksesibel. Aspek kendala untuk Malioboro menjadi ramah difabel berasal dari kesadaran masyarakat yang belum memahami pentingnya aksesibilitas difabel. Kendala lainnya berasal dari pembangunan Malioboro yang belum sepenuhnya berpihak pada kepentingan difabel. Selain hambatan terdapat aspek pendukung yaitu masih adanya sebagian masyarakat yang menyadari akan pentingnya aksesibilitas difabel di Malioboro dan regulasi yang cukup berpihak pada kepentingan difabel.
\end{abstract}

Kata Kunci: aksesibilitas, difabel, obyek wisata, Malioboro, Yogyakarta

\begin{abstract}
As citizens, the disabled must have the same rights in accessibility to public spaces, including the Malioboro tourism object in Yogyakarta City. So far, facilities for visitors with disabilities are still very minimal. This study aims to support city development policies to become a "Friendly City for Disabled Tourism". This study uses a qualitative descriptive approach, using observation, interview, documentation, and survey techniques. This research formulates the problem to find out the accessibility of disabled people in Malioboro tourism objects. The results of the study show that Malioboro tourism object is not yet accessible. The obstacle aspect for Malioboro to become disabled-friendly comes from the awareness of the people who do not understand the importance of accessibility. Another obstacle comes from the development of Malioboro which has not yet fully sided with the interests of the disabled. In addition to the obstacles there are supporting aspects namely there are still some people who are aware of the importance of the accessibility of disabled people in Malioboro and regulations that are quite in favor of the interests of the diffable.
\end{abstract}

Keywords: accessibility; diffable; tourism site; Malioboro; Yogyakarta

\section{PENDAHULUAN}

Daerah Istimewa Yogyakarta (DIY), dikenal sebagai daerah wisata bahkan terbesar nomor dua di Indonesia sehingga pembangunan fasilitas wisata terus ditingkatkan untuk kenyamanan pengunjung. Wisata DIY menyediakan berbagai wahana atau arena yang dapat dinikmati 
pengunjung, dan waktu libur banyak dijadikan tujuan wisata. Salah satu obyek wisata terkenal di Yogyakarta adalah Malioboro. Malioboro merupakan salah satu destinasi wisata utama yang berada di tengah-tengah Kota Yogyakarta dan sebagai pusat perbelanjaan berbagai cinderamata khas Jogja.

Selama ini fasilitas obyek wisata, selalu menunjang kebutuhan pengunjung yang normal. Sedangkan fasilitas untuk pengunjung difabel masih sangat minim. Berdasarkan hasil survei aksesibilitas di Malioboro dan Balaikota Yogyakarta yang dilakukan organisasi penyandang disabilitas di DIY yang mengatarnamakan Ohana Indonesia pada 12 September 2018, fasilitas khusus bagi para penyandang disabilitas di kawasan Malioboro Yogyakarta dinilai belum cukup aksesibel (Kabarkota, 2018). Sebagai masyarakat, difabel berhak untuk menikmati fasilitas rekreasi atau obyek wisata untuk melepas kepenatan, berlibur bersama keluarga dan lainnya. Namun hingga saat ini akses terhadap obyek wisata, masih banyak yang belum sempurna bisa di nikmati oleh kaum difabel di Kota Yogyakarta khususnya di Malioboro. Difabel mempunyai kesempatan yang sama seperti orang yang tidak cacat agar mereka mendapat kesempatan dalam segala aspek kehidupan dan penghidupan (Undang-Undang Republik Indonesia Nomor 4 Tahun 1997).

Pada tahun 2011 tercatat jumlah penyandang cacat di DIY sebanyak 29.110, yang terdiri dari 15.667 pria dan 13.443 wanita. Ini merupakan jumlah total dari keseluruhan penyandang cacat karena untuk penyandang disabilitas ini pun juga merupakan jumlah dari gabungan jenis cacat fisik maupun cacat mental (Dinas Sosial DIY Tahun 2010).

Meskipun jumlah kaum difabel di Kota Yogyakarta relatif kecil, aksesibilitas pada fasilitas umum di Kota ini seharusnya disediakan sebagai bentuk perwujudan hukum yang berlaku. Di Provinsi DIY sendiri, regulasi mengenai difabel diatur pada Perda Provinsi DIY No 4 Tahun 2012 tentang perlindungan dan pemenuhan hak-hak penyandang disabilitas.

Aksesibilitas itu sendiri merupakan kebutuhan penting bagi penyandang disabilitas dan merupakan bagian dari kehidupan manusia dalam kehidupannya. Karenanya, penyandang disabilitas dapat melakukan mobilitasnya ke berbagai tempat yang dikehendaki (Agenda, 2012). Akan tetapi tidak semua orang dapat mengalami akses yang memadai. Kaum difabel seringkali mengalami kesulitan dalam mengakses berbagai hal. Sedangkan aksesibilitas merupakan jembatan bagi difabel untuk dapat bersosialisasi dengan kehidupan luar.

Dalam Undang-Undang Dasar 1945 tertera persamaan hak bagi setiap warga negara tanpa membedakan kondisi fisik termasuk difabel. Dalam Undang-Undang Nomor 4 Tahun tentang Penyandang Cacat dan Peraturan Pemerintah Nomor 43 Tahun 1998 tentang Upaya Peningkatan Kesejahteraan Sosial Penyandang Cacat dinyatakan bahwa kesamaan kesempatan kaum difabel pada aspek kehidupan, dilaksanakan melalui penyediaan elemen aksesibilitas untuk menunjang kaum difabel agar dapat hidup bermasyarakat secara wajar dan mandiri (Setyaningsih, 2005). 
Oleh karena itu, sebagai warga negara, difabel juga semestinya mendapatkan perhatian dari pemerintah terkait aksestabilitas difabel pada obyek wisata di mana pun termasuk di Yogyakarta dan khususnya pada obyek wisata Malioboro. Kajian ini berfokus pada aksesibilitas difabel pada obyek wisata Malioboro di Kota Yogyakarta.

\section{METODE}

Penelitian ini terutama menggunakan metode penelitian kualitatif untuk dapat mengkaji tentang tema penelitian aksesibilitas difabel di obyek wisata Malioboro. Menurut Bogdan dan Taylor, metode kualitatif merupakan prosedur penelitian yang menghasilkan data diskriptif berupa kata-kata tertulis atau lisan dari orang-orang atau perilaku yang dapat diamati. (Moleong, 1993). Pengumpulan data primer dilakukan dengan melalui observasi, wawancara mendalam, dan dokumentasi.

Informan yang dipilih untuk diwawancara berasal dari berbagai unsur, yaitu dari pihak pemerintah (UPT Malioboro, Dinas Perhubungan dan Dinas Sosial), LSM, para difabel dan warga masyarakat biasa. Sedangkan Lokasi penelitian di kawasan wisata Malioboro kota Yogyakarta.

Sedangkan data sekunder didapat dari berbagai dokumen pendukung yang diperoleh selama penelitian. Selama dan setelah pengumpulan data, maka data diolah dengan analisa data kualitatif melalui tiga alur kegiatan yang terjadi secara bersamaan, yaitu reduksi data, penyajian data, dan penarikan kesimpulan.

Langkah terakhir adalah penarikan kesimpulan dan verifikasi. Dalam tahap akhir ini peneliti melakukan penjabaran makna dari data yang disajikan. Seperti yang dikemukakan Denzin dan Lincoln (2009: 307) untuk mengurangi kemungkinan terjadinya kesalahan interpretasi, digunakan prosedur-prosedur beragam termasuk pengumpulan data hingga mencapai titik jenuh (redundancy of data gathering) dan memperdebatkan prosedur-prosedur penjelasan atau teknik trianggulasi (Denzin, 1989; Goertz \& LeCompte, 1984).

Untuk mempertajam hasil penelitian, metode kuantitatif digunakan melalui survei di lapangan serta menyebar kuesioner terhadap responden kaum difabel. Sampel ditentukan secara pusposive sampling.

\section{HASIL DAN PEMBAHASAN}

\section{A. Gambaran Wilayah Lokasi Penelitian}

Malioboro adalah nama salah satu kawasan jalan dari tiga jalan di Kota Yogyakarta yang membentang dari Tugu Yogyakarta hingga ke perempatan Kantor pos Yogyakarta. Secara keseluruhan terdiri dari Jalan Margo Utomo, Jalan Malioboro, dan Jalan Margo Mulyo. Jalan ini merupakan poros Garis Imajiner Keraton Yogyakarta. Kawasan malioboro Stasiun 
tugu sampai dengan titik nol km. Kawasan Malioboro terletak sebelah selatan Stasiun Tugu yang membentang lurus sepanjang $1 \mathrm{~km}$, hingga ke perempatan Kantor Pos Yogyakarta atau daerah titik nol km. (Zakiyah, Husein, 2016).

Jenis wisata yang ditawarkan Malioboro adalah wisata belanja. Sepanjang kawasan Malioboro banyak berdiri bangunan-bangunan pertokoan dengan berbagai jenis barang yang dijual. Kemudian yang menjadikan ciri khas adalah bahwa Malioboro terkenal sebagai pusat perdagangan cinderamata dan oleh-oleh khas Yogyakarta dengan harga yang cukup terjangkau atau harga miring. Nuansa khas Yogyakarta juga nampak kental di Malioboro dengan berbagai ornamen dan sarana transportasi tradisional andong dan becak.

\section{B. Difabel dan Aksesibilitas Difabel di Obyek Wisata Malioboro}

Untuk mengetahui aksesibilitas difabel di Malioboro informasi yang sangat dibutuhkan adalah dari para difabel itu sendiri karena mereka yang merupakan subyek pelaku yang seharusnya memperoleh haknya untuk mengakses obyek wisata tersebut. Dari hasil wawancara, diperoleh hasil penelitian sebagai berikut:

\section{Aspek Sarana Prasana Fisik}

Aspek sapras fisik diawali dengan bahasan ketersediaan fasilitas penunjang di Malioboro yang baru tersedia bagi difabel netra. Hal ini diwujudkan dalam bentuk guiding block (Bapak Suparman,difabel daksa, 2017). Namun keberadaan guiding block yang baru justru tidak sebagus guiding block kuning sebelum Malioboro mulai dibangun. Tekstur yang lebih menonjol di satu sisi mempermudah teman-teman yang netra total. Akan tetapi bagi Pak Ajiwan yang low vision, warna sulit membedakan mana yang selokan dan mana yang guiding block.

Mengenai pembangunan pedestrian yang baru yaitu di sisi sebelah timur ada pendapat yang berbeda disampaikan oleh Pak Triyono dan bu Tari (keduanya merupakan difabel daksa, 2017). Pak Triyono berpendapat bahwa areal pedestrian pasca dibangun jauh lebih nyaman dilewati dibanding sebelum. Hanya saja akses di ujung-ujung jalan menuju Malioboro susah dilewati. Sedangkan bu Tari yang sehari hari menggunakan tongkat untuk berjalan merasa pedestrian malioboro yang sekarang lebih licin untuk dilewati dengan tongkatnya.

Sisi barat Malioboro sementara ini belum memiliki guiding block seperti pada sisi timur. Sedangkan guiding block pada emperan toko yang ada susah diakses antara lain karena banyaknya kios-kios pedagang kaki lima di sepanjang lajurnya. Tidak seperti pada pedestrian timur, guiding block di emperan toko (barat dan timur) tidak bersambung. Keadaan jalan yang diputus oleh gang dan tangga membuat lajur jalan terputus. Tuna netra yang lewat tak jarang harus berbalik arah karena hal tersebut. Disisi lain keberadaan pemandu wisata bagi teman 
netra amat diperlukan mengingat objek wisata Malioboro penuh dengan simbol rekreasi visual mulai dari pedestrian area, kios jualan hingga museum Benteng Vrederburg di paling selatan. Terutama museum yang mengandalkan display visual.

Salah satu kendala bagi teman-teman difabel adalah akses mencapai Malioboro. Jika menggunakan kendaraan umum, disampaikan oleh Pak Triono selaku perwakilan dari Ojek Difa, tidak ada tempat yang difungsikan sebagai wilayah antar jemput bagi difabel di Malioboro. Hal ini secara signifikan dirasa perlu untuk memudahkan difabel mencapai dan keluar dari lokasi Malioboro.

Cara lain mencapai Malioboro dengan menaiki transportasi publik seperti Trans Jogja. Cukup banyak catatan yang disampaikan oleh peserta diskusi terkait moda transportasi milik pemerintah tersebut. Pertama, posisi bus ketika berhenti untuk membuka pintu keluar masuk penumpang ketika di halte sangat beresiko. Kedua, jalan masuk dan keluar halte yang amat curam. Terkait halte, Pak Made (seorang difabel daksa) sudah pernah melakukan survey keliling kota naik bus dengan menggunakan kursi roda. Selain itu di dalam bus juga tidak ada pengait kursi roda.

Lokasi parkir yang hanya tersedia di jalan Abu Bakar Ali juga menjadi kendala bagi difabel yang membawa kendaraan pribadi. Sebelum area parkir tersebut dibangun, Komite disabilitas Kota Yogyakarta (yang didalamnya terdapat perwakilan dari difabel yaitu Pak Made), pernah menyampaikan masukan agar lantai satu dibangun area parkir difabel, karena kendaraan khusus difabel berbeda dengan kendaraan umumnya ada, lebih banyak modifikasinya menyesuaikan kebutuhan masing difabel dengan kedisabilitasan yang berbedabeda namun rencana tersebut tidak terealisasi. Persoalan lanjutan yang mengikuti setelah parkir adalah akses dari Jalan Abu Bakar Ali ke Malioboro. Trotoar tidak rata dan polisi tidur yang tidak diberi jalanan turun ( $\mathrm{ramp}$ ) serta keramaian lalu lintas membuat menyeberang jalan terasa rumit untuk difabel.

Seperti yang sudah diketahui, izin parkir di kawasan Malioboro sudah dicabut. Selain andong dan becak tidak boleh ada kendaraan bermotor jenis apapun diizinkan parkir di sepanjang Malioboro. Peserta diskusi hari itu sepakat bahwa kendaraan khusus difabel seharusnya masuk yang dikecualikan bersama andong dan becak. Regulasi ini dinilai kurang berpihak pada difabel.

Keberadaan fasilitas umum seperti toilet dan tempat ibadah yang ramah difabelpun belum ada. Tak jarang botol aqua menjadi teman kala toilet susah diakses. Toilet umum di Malioboro terlalu sempit dan licin sehingga berbahaya bagi difabel. Sebenarnya ada satu lagi fasilitas penunjang difabel yang di pasang pada lampu merah. Fungsinya untuk membantu 
difabel menyeberang jalan. Akan tetapi alat tersebut rusak tak terawat dan saat ini sudah tidak dapat berfungsi lagi. Selain itu lift pada Mall juga belum bisa dijadikan fasilitas penunjang bagi difabel, karena terlalu kecil. Tak jarang mereka menggunakan lift barang jika sedang berada di mall. Fasilitas ini belum bisa mengakomodasi kebutuhan difabel yang beraneka ragam.

Untuk menambah data berkaitan sarana prasarana fisik difabel di obyek wisata Malioboro, peneliti membagikan kuesioner kepada difabel untuk mengetahui pendapat mereka tentang kondisi fasilitas tersebut.

Sebagaimana menurut Demontoto (2005: 57) yang membagi aksesibilitas difabel terbagi atas dua macam yaitu aksesibilitas fisik dan non fisik, dan untuk aksesibilitas fisik berupa guilding block bagi difabel netra, tangga ramp, hand rail (pegangan tangan), lift, rambu-rambu lalu lintas dan tanda-tanda atau signage. Kemudian berdasarkan UndangUndang Nomor 4 Tahun 1997, UU. Nomor 8/2016 tentang Penyandang Disabilitas, dan Perda DIY Nomor 4/2012 tentang Perlindungan dan Pemenuhan Hak-Hak Penyandang Disabilitas maka fasilitas yang peneliti tanyakan adalah guidingblock askses transpotasi, parkir khusus difabel, lift, lift tangga/strairway, hand rail, toilet wastafel, telpon umum, ramp, kursi roda, audio visual atau running text, rambu lalu lintas dan tanda petunjuk, fasiltas penyebrangan, buku panduan dan peta dalam huruf Braille, serta pemandu wisata khusus. Dari berbagai fasilitas tersebut, peneliti membedakan kembali berdasar target penggunanya. Sehingga penelitian membedakannya dalam kondisi fasilitas bagi difabel secara umum, tuna netra, tuna rungu, dan tuna daksa.

Responden dari kuesiner ini adalah difabel yang peneliti temui secara sengaja maupun tidak sengaja di kawasan Malioboro. Responden merupakan difabel yang pernah berkunjung ke kawasan Malioboro. Responden yang peneliti ambil berjumlah 23 orang dengan keterbatasan berbeda dan latar belakang sosial ekonomi yang beragam juga. Responden diambil dari tiga kategori difabel yang memungkinkan berwisata secara mandiri pada obyek wisata Malioboro, yaitu difabel netra, difabel rungu dan difabel daksa. Berikut hasil dan analisis dari kuesioner tersebut dalam bentuk grafik dan penjelasannya: 
Grafik 1. Kondisi fasilitas bagi tuna netra, tuna rungu dan tuna daksa

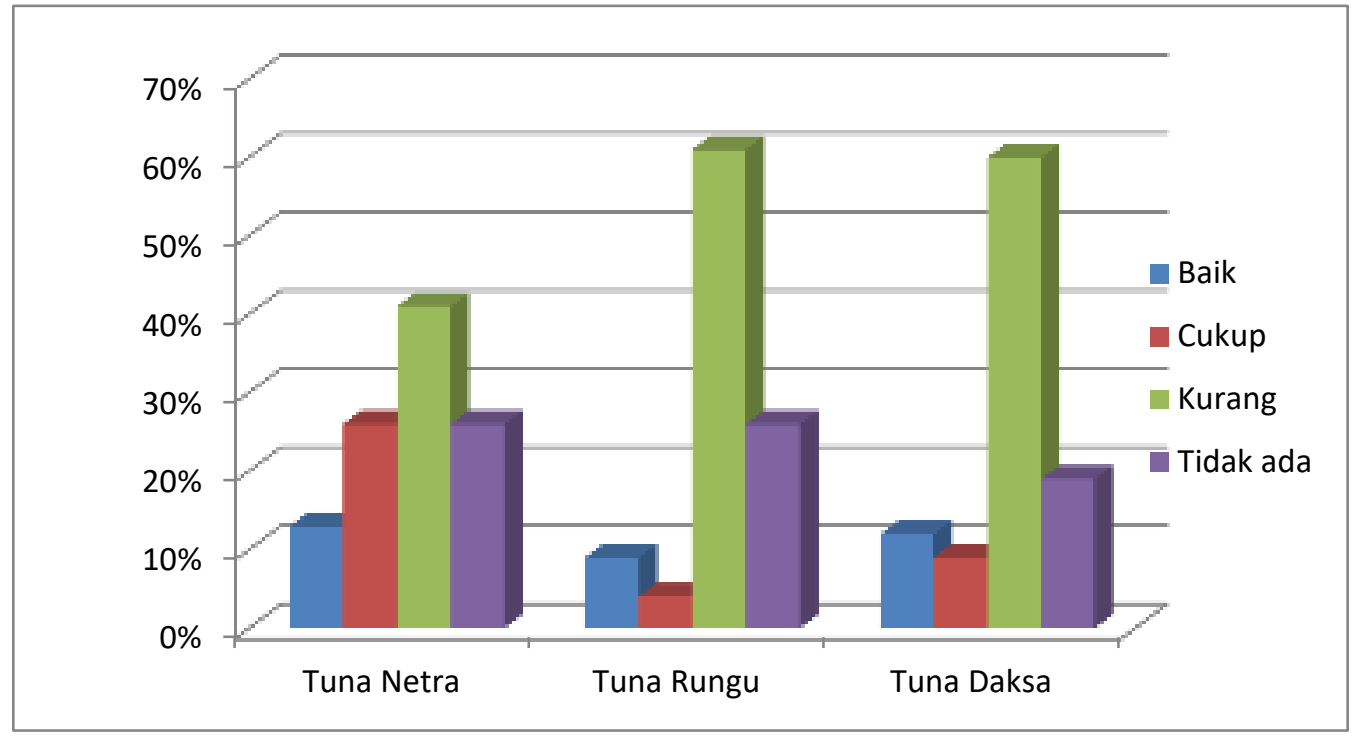

Berdasarkan grafik 1, sebanyak $41 \%$ responden menjawab bahwa kondisi fasilitas untuk tuna netra di kawasan Malioboro masih kurang. Sedangkan 13\% menjawab baik dan 26\% menjawab cukup. Dari seluruh responden, terdapat pula $20 \%$ yang beranggapan bahwa fasilitas tersebut tidak ada.

Sedangkan untuk tuna rungu, lebih dari setengah responden yaitu $61 \%$ menjawab bahwa kondisi fasilitas masih kurang. Hal itu sangat berbeda dari tanggangan responden yang menjawab baik yang hanya $13 \%$ dan cukup $4 \%$. Dari seluruh responden, terdapat juga $26 \%$ yang beranggapan bahwa fasilitas tersebut tidak ada.

Kondisi fasilitas pada tuna daksa, lebih dari setengah responden yaitu $60 \%$ menjawab bahwa masih kurang. Hal itu sangat berbeda dari tanggangan responden yang menjawab baik yang hanya $12 \%$ dan cukup 9\%. Dari seluruh responden, terdapat juga 19\% yang beranggapan bahwa fasilitas tersebut tidak ada. 
Grafik 2. Kondisi fasilitas bagi difabel secara umum

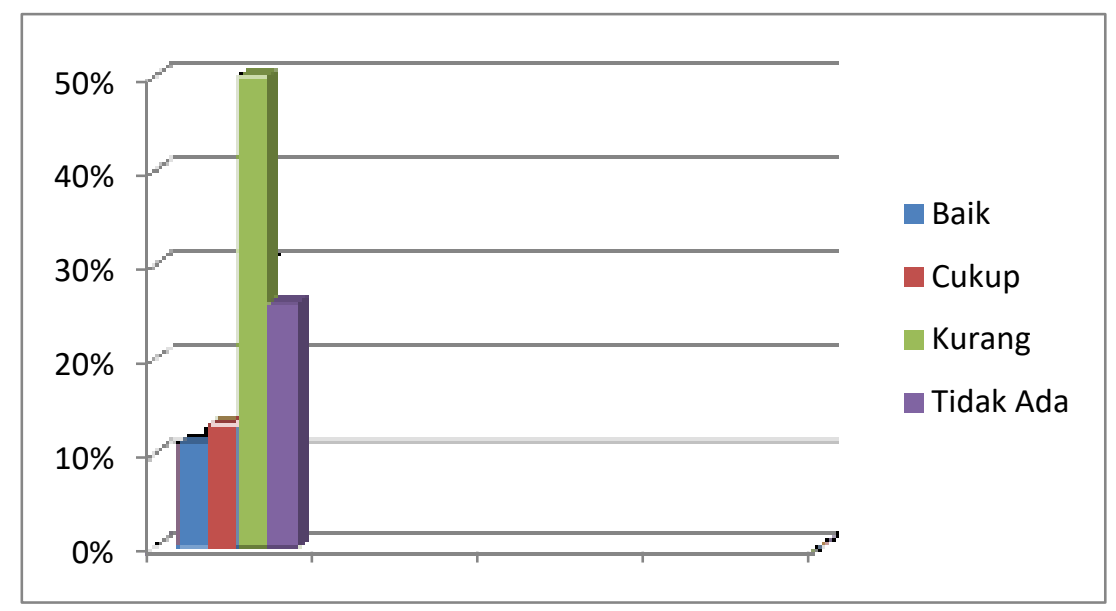

Berdasarkan grafik di atas, 50\% responden beranggapan bahwa kondisi fasilitas bagi difabel secara umum masih kurang. Hasil tersebut sangat berbeda jika dibandingkan dengan jawaban baik yang hanya 11\% dan 13\% menjawab cukup. Meski demikian, masih terdapat $26 \%$ responden yang beranggapan bahwa fasilitas yang dimaksud tersebut tidak ada.

Dari keseluruhan grafik dapat dijabarkan bahwa tuna rungu menjadi difabel yang fasilitasnya lebih banyak tidak adanya dibanding difabel tuna daksa dan tuna netra. Tuna rungu paling kurang kondisi fasilitasnya dibanding difabel tuna daksa dan tuna netra. Tuna netra menjadi difabel paling banyak terkategori baik dan cukup kondisi fasilitasnya dibanding difabel yang lainnya. Sedangkan secara umum fasilitas untuk difabel di Malioboro belum aksesibel karena hanya 24\% $(13 \%+11 \%$, yang menjawab baik dan cukup untuk sarana prasarana difabel), sedangkan yang menjawab sebaliknya ada $76 \%((50 \%+26 \%$, yang menjawab kurang dan tidak ada fasilitas tersebut).

Dari hasil penelitian dengan observasi, FGD, wawancara dan kuesioner dalam sarana prasarana penunjang aksesibilitas difabel di obyek wisata Malioboro, ternyata masih banyak kekurangan. Yang tersedia lebih banyak untuk difabel netra berupa guiding block, namun dengan catatan untuk difabel netra yang low vision (penyandang tuna netra dengan sedikit masih bisa melihat) guiding block pedestrian baru yang berwarna perak menyilaukan, juga guiding block antara timur dan barat tidak bersambung sehingga menyulitkan difabel netra yang menuju pedestrian lainnya, dan masih banyak bagian guiding block pedestrian sebelah timur (pedestrian lama) yang tertutupi pedagang kaki lima. Selebihnya fasilitas pemandu wisatadan fasilitas audio visual yang dibutuhkan difabel netra juga tidak ada. 
Sedangkan untuk difabel daksa sudah ada fasilitas ramp namun belum maksimal seperti harapan, seperti di halte dan lokasi parkir Abu Bakar Ali masih menyulitkan untuk difabel daksa mengakses. Sarana transportasi juga kurang aksesibel karena banyak menyulitkan difabel daksa. Sarana di pertokoan seperti lift, tangga berjalan, ramp juga kurang akses. Kemudian toilet umum serta tempat ibadah juga tidak aksesibel.

\section{Aspek Social Awareness}

Selanjutnya yang berkenaan dengan kesadaran sosial mengenai aksesibilitas difabel di obyek wisata Malioboro, Pak Abas peserta FGD mengungkapkan salah satu kesulitan difabel di Malioboro adalah dalam menikmati wisata belanja. Pertokoan dan mall di Malioboro belum sepenuhnya accessible bagi difabel, karena beluma ada kesadaran berbagai pihak. Seperti misalnya dari pemerintah dalam rencana pembangunan, memang aspek aksesibilitas difabel ini kurang menjadi perhatian.

Ojek Difa (Ojek yang dikendalikan/supirnya difabel) sering mendapat perlakuan kurang menyenangkan ketika sedang menurunkan penumpang di Malioboro. Klakson dan teriakan untuk cepat bergerak sudah sering diterima. Ojek Difa memang membutuhkan waktu lebih lama memang untuk menurunkan penumpang. Apalagi jika penumpangnya juga difabel. Ada juga kesaksian peserta FGD yang saat akan menaiki trotoar dengan susah payah di malioboro yang tidak ada ramp-nya, tidak ada satupun warga yang membantu kecuali wisatawan bule (wisatawan asing) yang .membantu mengangkatkan kursi rodanya. Ini menunjukkan kurang peka dan berempatinya warga sekitar terhadap kebutuhan difabel.

Para peserta FGD sepakat, walaupun sudah ada peraturan tertulis untuk mewujudkan lingkungan yang inklusi dan mulai tersedianya sarana prasarana ramah difabel jika aspek manusianya belum benar akan percuma. Sebenarnya laporan, saran dan advokasi sudah dilakukan, akan tetapi sering terjadi miss di lapangan. Banyak kebijakan pemerintah yang belum mendukung difabel. Sebagai contoh aturan tentang kendaraan modifikasi terstandar yang belum ada. Pada satu sisi pemerintah terlebih dahulu mengeluarkan surat peringatan salah satunya kepada Ojek Difa.

Dari hasil FGD terlihat banyak peserta berpendapat segala permasalahan birokrasi yang terjadi di pemerintah terkait difabel dikarenakan belum ada komitmen yang serius dari pemerintah untuk serius menggarap pengembangan difabel sendiri. Mereka menghendaki adanya pergeseran pandangan bahwa difabel bukan sebagai obyek melainkan subyek, termasuk dalam hal aksesibilitas difabel di ruang publik, supaya dalam pembangunan mereka benar-benar dilibatkan tidak hanya saat perencanaan namun juga hingga implementasi 
pembangunan, agar setiap fasilitas diuji cobakan dulu pada difabel sebelum permanen digunakan.

\section{Kesadaran Masyarakat dalam Aksesibilitas Difabel di Obyek Wisata Malioboro}

Awal meneliti masyarakat sekitar Malioboro pada tanggal 22 Agustus 2017, peneliti mewawancara informan sebut saja Pak Sugeng yang berprofesi sebagai tukang becak motor dan Pak Budi sebagai tukang becak kayuh, mereka berdua berumur sekitar 45 tahun. Pak Sugeng mengetahui difabel hanya tuna netra yang berjalan di garis silver yang dulu sebelum Malioboro di bangun ulang berwarna kuning. Pak Budi menambahkan bahwa untuk berinteraksi dengan difabel ia jarang melakukan tetapi jika mereka (tuna netra) mengalami kesusahan informan pernah membantu seperti menyebrangkan jalan. Mengenai fasilitas untuk difabel Pak Sugeng dan Pak Budi hanya sebatas mengetahui tempat miring di TransJogja sebagai tempat kursi roda menaiki selter.

Kemudian peneliti mewawancarai informan bernama Pak Puji dan Pak Anung yang berprofesi sebagai petugas jaga Malioboro (Jogoboro), usia mereka telihat masih muda sekitar 30 tahun. Pak Anung bercerita bahwa dirinya mengetahui penyandang difabel sebatas tuna daksa, tuna netra, tuna rungu. Meskipun Pak Anung dan Pak Puji belum mengetahui istilah aksesibilitas untuk difabel, mereka sering beberapakali membantu tuna netra menyebrang jalan atau yang terperosok saat turun angkutan umum. Pak Puji menambahkan bila di tolong terkadang difabel menolak dengan sopan, sehingga membuat dirinya dan teman polisi kraton yang lain mengangap kejadian para difabel terperosok adalah wajar dan hanya merasa berempati.

Informan berikutnya adalah seorang ladies informasi di Malioboro Mall sebut saja Nia umur sekitar 22 tahun, Nia bercerita belum mengetahui arti difabel, dia hanya mengetahui tuna netra dan jarang berkomunikasi dengan mereka. Mengenai fasilitas untuk difabel Nia menjawab cukup karena menurutnya Guiding Block berwarna silver dilihat kuat dan awet jadi membantu sekali difabel untuk berjalan tetapi dia memberi saran bila pingir trotoar sepertinya bisa di pasang pagar kawat agar tuna netra tidak keluar jalur dan masuk jalan raya saat berjalan.

Pada waktu selanjutnya, tanggal 25 Agustus, salah satu informan yang peneliti wawancara adalah Ibu Mawar. Informan merupakan pedagang di kawasan Malioboro. Ibu Mawar berusia sekitar 45 tahun. Menurut Ibu Mawar, difabel merupakan orang-orang yang memiliki kecacatan. Selama 20 tahun berjualan di kawasan Malioboro, informan belum pernah berinteraksi maupun berkomunikasi dengan mereka. Informan hanya pernah membantu mereka dalam bentuk mempersilahkan untuk berjalan dan mencari nafkah di sana. Ibu Mawar juga menyebutkan bahwa bantuan langsung yang sering diberikan adalah berupa uang. Ibu Mawar memberi informasi bahwa fasilitas untuk difabel hanya garis-garis timbul di jalur pedestrian yang bernama guiding 
block. Fasilitas tersebut dianggap sudah berfungsi dengan baik. Ibu Mawar tidak tahu tentang fasilitas lain yang diperuntukkan bagi difabel. Baginya fasilitas guiding block itu pun cukup bagi mereka dan tidak perlu ditambahkan fasilitas lain.

Peneliti juga mewawancarai dua anak sekolah yang bernama Melati dan Rosa. Mereka berusia 16 tahun. Informan beranggapan bahwa difabel cenderung orang yang tunanetra. Kedua informan juga belum pernah berinteraksi ataupun berkomunikasi langsung dengan difabel. Pemberian bantuan untuk difabel juga sebatas pada pemberian dana yang dilakukan melalui kegiatan amal di sekolah. Sepengetahuan mereka, fasilitias bagi difabel di Malioboro sudah ada yaitu geronjalan di jalur pedestrian yang bernama guiding block. Fasilitas tersebut dianggap sudah berfungsi dengan baik. Menurut mereka, fasilitas bagi difabel sudah cukup tersedia di Malioboro. Kekurangannya hanya pada dana yang seharusnya dapat diberikan pada difabel.

Informan selanjutnya yang peneliti wawancarai bernama Mas Nono, umur 24 tahun, asal Wonosari. Informan rupanya lebih familiar menyebut teman-teman difabel dengan istilah cacat untuk difabel fisik dan idiot untuk difabel mental. Informan mengaku jarang sekali melihat dan tidak pernah berinteraksi sama sekali dengan difabel baik di Malioboro maupun tempat lain. Informan tidak tahu menahu tentang keberadaan fasilitas penunjang difabel di Malioboro apa saja. Walaupun tidak tahu menahu tentang fasilitas difabel, Informan berpendapat bahwa fasilitas penunjang bagi difabel di Malioboro penting untuk diadakan.

Informan berikutnya bernama Mas Faza, pria berusia 29 tahun dan pedagang baju muslim yang sedang backpackeran ke Jogja. Walaupun jarang bertemu dengan difabel dia sekali waktu pernah bertemu dengan seorang difabel yang kakinya pincang sedang berjualan. Bentuk membantu difabel diterjemahkan oleh Informan dengan melarisi dagangan si penjual yang tak laku-laku. Selain hal tersebut, Informan belum mencoba membantu dengan cara lain atau melaporkan kesulitan difabel kepada pihak pemerintah, lembaga, atau orang lain. Ketika menyebut fasilitas difabel, Informan hanya menyebutkan ojek khusus difabel yang kebetulan pernah ia lihat liputannya di televisi. Guiding block di sebelah Informan persis tidak disinggung.

Informan lainnya adalah seorang siswi SMA Al Islam Surakarta kelas 11. Bersama kedua orang teman sekelasnya berlibur ke Jogja. Informan tidak pernah melakukan interaksi apapun yang berkaitan dengan difabel. Bagi Informan Malioboro adalah tempat wisata jalan-jalan yang menyenangkan. Oleh karena itu, jika fasilitas untuk difabel tidak dilengkapi ia membayangkan bagaimana mereka bisa senang-senang menikmati Malioboro seperti dia dan kedua temannya.

Shela, 26 tahun menjadi informan selanjutnya. Ia adalah karyawan dari seorang pedagang kaki lima di kawasan Malioboro. Ketika ditemui disela-sela shift jaga dagangan, Informan langsung mengasosiasikan difabel pasti adalah seorang peminta-minta. Pengertiannya tentang 
difabel pun langsung mengarah pada pengertian tentang difabel netra. Pernyataan Shela ini dikarenakan setiap hari ia bertemu dengan sepasang suami istri tuna netra yang sehari-hari mengemis di Malioboro.

Kerap kali Informan juga membantu sepasang tuna netra ini jika mereka hendak menyeberang dari sisi timur ke sisi barat Jalan Malioboro. Meskipun posisi gerobak jualan informan persis di samping guiding block, namun pertanyaan seputar fasilitas untuk difabel dijawab dengan gelengan kepala. Informan juga mengutarakan bahwa ia memiliki kesibukan mencari nafkah di Malioboro sehingga tidak bisa terlalu memperhatikan hal-hal soal difabel di Malioboro.

Dari hasil wawancara dengan masyarakat sekitar Malioboro, mayoritas mereka tidak mengetahui istilah difabel dan aksesiilitas difabel. Setelah diberi sedikit pengertian sebagian mereka mengungkapkan mengetahui difabel hanya sebatas tuna netra dan pengguna kursi roda (tuna daksa). Terdapat informan yang beranggapan bahwa difabel sebatas orang-orang yang memiliki kecacatan dan cenderung menjadi pengemis atau pengamen. Anggapan ini juga terlihat dari jenis bantuan yang informan berikan yaitu dalam bentuk uang dan mempersilahkan untuk mencari nafkah. Sedangkan mengenai sikap saat melihat difabel mengalami kesusahan seperti menyebrang jalan, kebanyakan dari informan bersedia membantu.

Kaitan aksesibilitas difabel, beberapa Informan merasa cukup dengan adanya fasilitas garisgaris timbul di jalur pedestrian Malioboro. Sebagian informan lain memaparkan mengenai guiding block dan ramp yang mereka ketahui sebagai jalanan berwarna silver dan jalan miring untuk penguna kursi roda. Namun untuk sebagian informan lainnya belum mengetahui apa saja fasilitas difabel di Malioboro. Bahkan banyak informan tidak tahu tentang fasilitas yang sebenanrnya sudah ada di Malioboro yaitu guiding block.

Terdapat informan yang berpandangan, apabila fasilitas untuk difabel dibuat semakin lengkap maka akan banyak difabel yang terdapat di Malioboro. Sehingga informan merasa tidak setuju terhadap hal itu karena ia beranggapan bahwa lebih baik jalur pedestrian digunakan untuk pejalan kaki saja. Ini memperlihatkan masih terdapat masyarakat yang belum sepenuhnya memiliki kesadaran akan hak difabel akan aksesibilitasnya di obyek wisata Malioboro yang termasuk sebagai ruang publik. Namun ada pula informan yang menyatakan bahwa fasilitas untuk difabel di Malioboro penting dan ada yang cukup memahami jika difabel juga membutuhkan tempat wisata yang nyaman untuk mereka. 


\section{Pemerintah dalam Aksesibilitas Difabel di Obyek Wisata Malioboro}

Dalam perjanjian internasional Konvensi Perserikatan Bangsa-Bangsa tentang Hak-Hak Penyandang Disabilitas, dalam pasal 4 disebutkan beberapa item yang merupakan kewajiban sebuah Negara dalam rangka menjamin hak-hak penyandang disabilitas terwujud dan tak terabaikan. Negara yang Notabene terdapat unsur Pemerintah sangat mempunyai peranan penting dalam hal tersebut termasuk dalam perwujudan hak disabilitas mendapatkan akses yang mudah pada ruang-ruang publik seperti obyek wisata.

Pemerintah sebenarnya telah menindaklanjuti dalam segi payung hukum mengenai aksesibilitas difabel. Hal tersebut sebagaimana terejawantah dalam beberapa produk hukum yang berpihak pada difabel dari sekup nasional hingga daerah, dan untuk kota Yogyakarta bahkan sudah ada Perwal tentang Komite Disabilitas, yang berdasr keterangan pihak Dinsos berguna untuk mempercepat langkah-langkah pemenuhan hak-hak difabel. Produk hukum yang ada tersebut adalah UU 19/2011 tentang Pengesahan Konvensi Perserikatan Bangsa-Bangsa tentang Hak-Hak Penyandang Disabilitas, UU 8/2016 tentang Penyandang Disabilitas, Perda DIY 4/2012 tentang Perlindungan dan Pemenuhan Hak-Hak Penyandang Disabilitas, Perda Kota Yogyakarta (yang saat penelitian berlangsung masih dalam proses pembahasan di Pansus DPRD Kota Yogyakarta), dan Perwal Kota Yogyakarta 16/2017 tentang Komite Perlindungan dan Pemenuhan Hak-Hak Penyandang Disabilitas (Peraturan Walikota Nomor 8 tahun 2014 tentang Komite Perlindungan dan Pemenuhan Hak-Hak Penyandang Disabilitas).

Dinas-Dinas terkait yang diwawancara peneliti umumnya mengetahui adanya peraturanperaturan hukum tersebut. sebagaimana informasi yang diberikan UPT Malioboro, "Keputusan Jogja mengejar gelar inklusif diikuti dengan berbagai produk hukum”. Walaupun tidak bisa secara detil menyebutkan produk hukum kebijakan ini, Informan UPT Malioboro menekankan pemerintah serius dengan hal ini. Sedangkan pihak Dishub mengungkapkan, "Dalam pembangunan sarana dan prasarana bagi difabel, dinas di Kota Yogyakarta sendiri belum terdapat landasan hukumnya yang berupa peraturan daerah. Namun proses eksekusi di lapangan didasari oleh peraturan daerah provinsi tahun 2014 tentang hak difabel. Dari hal tersebut menunjang munculnya peraturan walikota pada tahun 2014. Peraturan tersebut dibuat oleh eksekutif dan legislatif daerah tersebut."

UPT Malioboro mengungkapkan, secara umum di Yogyakarta sedang digalakkan program pembangunan inklusi. Dinsos menjelaskan pembangunan inklusi adalah pembangunan dengan pendekatan untuk membangun dan mengembangkan lingkungan sosial dan fisik yang semakin terbuka dan menyeluruh. Untuk merealisasikan rencana yang ada dalam peraturan yang sudah dibuat, pemerintah membuat sebuah komite yang beranggotakan wakil dari pihak-pihak yang 
bersangkutan dengan peraturan itu. Dengan adanya komite tesebut, diharapkan seluruh pihak yang terlibat dapat mengetahui dengan pasti realisasi dari peraturan pemerintah itu. Selain itu, diharapkan komite dapat membantu sosialisasi adanya realisasi kebijakan kepada seluruh pihak. Sehingga realisasi tersebut diharapkan dapat bermanfaat bagi semua kalangan.

Untuk menyebarluaskan produk hukum beserta program yang mengikutinya membutuhkan sosialisasi kepada pihak terkait. Pihak UPT Malioboro menyatakan sementara ini, sosialisasi mengenai produk hukum pemerintah menyangkut difabel dipublikasikan via sosial media, aksi sosial dan humas pemkot. Sedangkan Dinas Perhubungan juga mengklaim sudah melakukan sosialisasi. Sosialisasi tersebut ditujukan bagi semua pihak. Bahkan dinas melakukan sosialsasi pada berberapa sekolah. Sehingga diharapkan agar manfaat dari kebijakan dan realisasinya dapat dirasakan oleh seluruh pihak.

Sosialisasi tentunya sangat penting, selain memberikan pengetahuan dan kesadaran pada difabel atas hak-haknya jg sangat dibutuhkan untuk membangun kesadaran masyarakat agar memahami hal tersebut sehingga ikut berperan serta aktif pula dalam mewujudkannya karena tanpa kesadaran masyarakat tentu juga akan banyak kendala yang terjadi. Namun sayangnya sebagaimana disampaikan pihak Dinsos kesadaran masyarakat masih perlu dibangun dalam hal ini, masih sering terjadi diskriminasi di ruang ruang publik terhadap difabel. Pihak UPT Malioboro memberi pendapat, " Masalah kepedulian para pengunjung dan warga di sekitar Malioboro terhadap difabel, menurut Informan tidak bisa disamaratakan. Sejauh pengamatan Informan, biasanya orang Jogja asli punya kepekaan yang tinggi dan pasti membantu atau minimal melapor ke UPT atau Jogoboro untuk minta bantuan. Sedangkan di Malioboro sebenarnya lebih banyak pengunjung luar daripada orang lokal. Hal ini yang dirasa menjadi tantangan mengenai karakteristik orang yang lebih beragam”.

Selain sosialisasi hal penting lainnya adalah realisasi perwujudan dari peraturan yang ada. UPT Malioboro menyatakan salah satu langkah nyatanya adalah pembangunan trotoar dengan guiding block. Informan menceritakan sudah banyak wisatawan netra yang bisa berjalan dari Abu Bakar Ali ke Kraton dan kembali lagi (karena sudah ada guiding block tersebut). Mewakili UPT Malioboro, informan menuturkan hanya ada dua fasilitas yang khusus diperuntukkan bagi difabel, yaitu guiding block dan lampu penyeberangan (yang rusak karena tak terawat). Mengenai lampu penyeberangan, atau disebut pelikan cross, peneliti dalam observasi mendapati ada empat buah dan terletak pada di beberapa titik, setelah mencoba fasilitas tersebut ternyata rusak semua. Namun pihak Dishub mengklaim saat beberapa waktu lalu di bulan puasa masih berfungsi. Fasilitas lainnya, terdapat halte bus Trans Jogja yang sudah memiliki ramp. Namun demikian pihak Dishub mengakui halte yang tersedia masih belum ramah difabel. Hal itu dikarenakan, 
kemiringan ramp pada halte masih cukup curam yaitu sekitar 45 derajat. Selain fasilitas yang sudah disebut tadi, Informan juga menepis adanya area parkir khusus bagi difabel di Malioboro. Semua dipusatkan di Abu Bakar Ali, dan belum ada parkir khusus difabel di Taman Parkir tersebut.

Sedangkan berkaitan dengan pelayanan di kawasan Malioboro, UPT Malioboro yang merupakan unit pelayanan teknis kepada masyarakat baik pelaku wisata maupun wisatawan yang berkunjung berusaha memberikan pelayanan terbaik termasuk kepada difabel. UPT menyampaikan pada peneliti bahwa teman-teman difabel menjadi prioritas untuk dilayani bagi UPT. Selain itu, permintaan untuk membantu difabel di Malioboro pun banyak masuk dari para wisatawan Malioboro. Pelayanan terhadap difabel oleh UPT dinilai Informan sudah sangat baik. Menurut Informan, pihak UPT menyatakan siap membantu tanpa segan. Salah satunya adalah karena ada arahan dari walikota secara langsung melalui Perwal untuk hal yang satu ini. Ketika peneliti bertanya tolok ukur mengukur capaian dari produk hukum peraturan tentang difabel, Informan menegaskan tidak ada. Prinsip UPT bagi Informan ialah melayani siapapun yang membutuhkan bantuan di area Malioboro. Sebagaimana contohnya keberadaan pengamen difabel di Malioboro juga menjadi salah satu yang diatur oleh UPT Malioboro. Tidak dilarang melainkan ditempatkan di lima titik sepanjang Malioboro sehingga tidak mengganggu kenyamanan dua belah pihak (wisatawan maupun pengamen difabel itu sendiri).

Mendengar beberapa cerita Informan seputar fasilitas bagi difabel dan bantuan-bantuan UPT, peneliti dapat melihat bahwa pihak UPT cukup sadar akan kebutuhan teman-teman difabel. Pihak UPT menindaklanjuti masukan dari masyarakat terutama soal fasilitas untuk difabel. Diakui Informan, pihaknya sudah sering menerima masukan dari warga baik secara umum, maupun khusus masalah difabel seperti penyediaan sarana tambahan. Akan tetapi Informan menyampaikan bahwa pihak UPT tidak punya wewenang bertindak untuk masalah yang itu. Sehingga masukan dari warga diteruskan ke Kota dan Provinsi yang memiliki wewenang masalah pembangunan sarana prasarana.

Menurut informan dari UPT, masalah sebenarnya terletak di koordinasi yang buruk antara progress pembangunan kota dan provinsi. Banyak juga fasilitas yang sudah ada kemudian rusak seperti jaringan kabel dan radio UPT Malioboro. Pembangunan di sisi utara tempat becak biasa mangkal dan penggusuran juru parkir dari wilayah Malioboro tanpa sosialisasi merupakan salah dua bentuk kurangnya koordinasi pemerintah kota dan provinsi. Akibatnya di lapangan, protes hingga ricuh terpaksa ditangani oleh pihak UPT Malioboro yang kondisinya tidak diikutkan dalam koordinasi pembangunan. Informan UPT juga menjabarkan, hambatan atau kendala yang dialami UPT terkait pelayanan terhadap difabel adalah ketika pada hari-hari ramai seperti tahun 
baru, lebaran, dan musim libur panjang. Membludaknya pengunjung di hari-hari tersebut membuat ruang gerak di Malioboro semakin terbatas. Guiding block sering diabaikan jika massa yang datang sampai berhimpitan. Menyeberang jalan juga menjadi kesusahan tersendiri.

Pembangunan Malioboro dengan wajah barunya memang belum selesai dibangun. Grand design pembangunan Malioboro menurut Informan merupakan design dari pemenang kompetisi design Malioboro. Pembangunan sepenuhnya dipegang oleh PUESDM (Provinsi) mulai dari alokasi dana hingga penunjukkan investor. UPT hanya berperan mengawal proses di lapangan dan koordinasi dengan pihak-pihak yang terkai. $t$ di lapangan.

Informan dari Dishub menjabarkan bahwa kawasan Malioboro direncanakan hanya dapat dilewati oleh andhong, becak, bis Transjogja saja. Sehingga jalan kendaraan bermotor pribadi akan dialihkan dan direncanakan akan membuat tempat parkir baru di sekitar Hotel Melia Purosari. Dengan rencana tersebut, ditujukan agar kawasan Malioboro dapat nyaman digunakan oleh pejalan kaki. Dinas Perhubungan juga mencanangkan akan membuat halte yang lebih ramah difabel. Dalam rencana itu, ramp pada halte akan dibuat melingkar dengan derajar kemiringan sekitar 20 derajat, sehingga kemiringannya tidak curam seperti sekarang dan mudah dilalui difabel.

Dari data yang telah didapat, pemerintah dalam segi regulasi telah membuat berbagai macam peraturan dari sekup nasional hingga daerah untuk mewujudkan aksesibilitas pada difabel termasuk pada obyek wisata sebagai ruang publik. Bahkan untuk Kota Yogyakarta, walikota telah mengadakan Komite Disabilitas. Namun dalam implementasi berbagai peraturan tersebut saat ini belum maksimal dan masih dalam proses menuju penyempurnaan. Informan-informan dari pihak pemerintah mengakui kekurangan tersebut. Fasilitas ramah difabel di Malioboro diakui baru sebatas adanya guiding block, pelikan crossing atau rambu penyeberangan untuk difabel yang ternyata sudah tidak berfungsi, dan halte dengan sudah ada ramp namun masih terlalu curam kemiringannya untuk dilewati difabel. Permasalahan atau kendala dalam pembangunan Malioboro terungkap adanya kurang kordinasi antara berbagai instansi yang terlibat.

\section{PENUTUP}

\section{Kesimpulan}

Aksesibilitas difabel di obyek wisata Malioboro masih jauh dari kondisi aksesibel. Pada obyek wisata ini hanya tersedia sebagian kecil fasilitas dan sarana prasarana yang seharusnya ada untuk difabel, yaitu terutama berupa guiding block dan ramp yang ada di sekitar lokasi. Fasilitas tersebut juga masih mendapat catatan karena belum sepenuhnya mudah digunakan untuk pengguna dari difabel. Sedangkan fasilitas dan sarana prasarana lainnya yang menunjang aksesibilitas difabel seperti 
toilet, tempat parkir, rambu-rambu, lift dan beberapa fasilitas lainnya yang ramah difabel belum tersedia. Sehingga terlihat fasilitas yang cenderung sudah ada hanya untuk golongan difabel tertentu, yaitu difabel netra dan difabel daksa.

Pembangunan Malioboro akan terus dilakukan hingga tahun 2020. Kompleksitas pembangunan Malioboro yang dilaksanakan pihak-pihak dari pemerintah menjadi salah satu kendala dalam mewujudkan aksesibilitas difabel.. Kemudian pada sisi implementasi, miss kordinasi dan kurang melibatkan lembaga terkait yang memahami situasi di lapangan menjadikan kendala pula. Kurangnya melibatkan para difabel saat uji coba pembangunan juga menjadi salah satu aspek penting yang menjadikan Malioboro belum aksesibel untuk difabel kunjungi.

Kemudian kendala lain dari kurangnya aksesibilitas difabel di obyek wisata Malioboro terkait masalah kesadaran masyarakat dalam pembangunan ramah difabel pada lokasi tersebut. Masyarakat sekitar belum sepenuhnya memahami pentingnya obyek wisata Malioboro yang ramah untuk dikunjungi wisatawan difabel. Kepedulian sebagian besar masyarakat umumnya hanya pada sebatas rasa kasian.

Dari kendala yang ada, terdapat pula aspek pendukung untuk ke depan pembangunan Malioboro menjadi lebih aksesibel. Aspek tersebut adalah kesadaran masyarakat yang tidak sepenuhnya tidak perduli akan aksesibilitas difabel di Malioboro, masih ada bagian masyarakat yang sungguh sangat perduli dengan hal tersebut termasuk masyarakat difabel, LSM dan sebagian masyarakat umum yang sungguh memperjuangkan pembangunan ramah difabel. Kemudian aspek regulasi yang ada dari pemerintah pusat, provinsi hingga daerah, dalam hal ini Kota Yogyakarta cukup menunjukkan keberpihakkan pada pembangunan pro difabel.

\section{Saran}

Dari kesimpulan penelitian di atas, peneliti menyarankan beberapa hal. Pertama, regulasi perlu dipertahankan dan secara berkala ditinjau ulang dan terus disempurnakan agar menyesuaikan kebutuhan difabel akan aksesibilitas di berbagai lini yang berkembang seiring perkembangan masyarakat. Kedua, implementasi kebijakan di lapangan termasuk dalam perencanaan pembangunan Malioboro sangat perlu melibatkan berbagai pihak utamanya yang benar-benar memahami kondisi real Malioboro, dan harus melibatkan para difabel sampai tahap uji coba dan evaluasi dari pembangunan Malioboro. Ketiga, peningkatan kesadaran masyarakat luas akan pentingnya pemenuhan aksesibilitas difabel di obyek wisata Malioboro perlu terus dilakukan dengan berbagai upaya termasuk sosialisasi yang efektif dan tepat sasaran secara berkesinambungan. 


\section{DAFTAR PUSTAKA}

AGENDA, 2012. Disability in Southeast Asian Countries. diunduh 10 Desember 2013 pada http://www2.agendaasia.org/index.php/information/disability-in-asean

Agus Diono, Mujaddid, Fanciscus Adi Prasetyo, \& Didik Budijanto. (2014). Situasi Penyandang Disabilitas. Buletin Jendela Data dan Informasi Kesehatan, 1-56.

Aziz, Safrudin. 2014. Perpustakaan Ramah Difabel. Yogyakarta: Ar-Ruzz Media.

Demortoto, Argyo. 2005. Menyibak Sensitivitas Gender dalam Keluarga Difabel. Surakata: UNS Press.

Denzin, Norman K, Lincoln,Yvonna S. 2009. Handbook of Qualitatif Research. Yogyakarta: Pustaka Pelajar.

Dinas Sosial, Kota Yogyakarta. 2017. Menuju Kota Yogyakarta yang Inklusif melalui Kecamatan Inklusi, Materi Penyuluhan, Yogyakarta.

Faud, Bahrul. Difabel, Sebuah Simbol Perlawanan Ideologi. Cak Fu. http://cakfu.info/2010/08/difabel-sebuah-simbol-perlawanan-ideologis/. Diakses 13 Januari 2017.

Handoyo, Febri, dkk. 2017. Paket Wisata bagi Difabel di Yogyakarta. Jurnal Pariwisata Terapan, Vol. 1, No. 2.

Hernowo, Bimo. 2005. Aksesibilitas Difabel Sebagai Tuntutan Hak Azazi. Paper.

Kabarkota, Malioboro dinilai belum cukup aksesibel bagi penyandang disabilitas https://kabarkota.com/malioboro-dinilai-belum-cukup-aksesibel-bagi-penyandang-disabilitas/. Diakses tanggal 20 Desember 2018

Maftuhin, A. 2016. Mengikat Makna Diskriminasi: Penyandang Cacat, Difabel, dan Penyandang Disabilitas. INKLUSI, 3(2), 139-162.

M. Syafi'ie, dkk. 2014. Potret Difabel Berhadapan dengan Hukum Negara. Yogyakarta: SIGAB.

Moleong, J Lexy. 2012. Metodologi Penelitian Kualitatif. Bandung: Remaja Rosdakarya,

Peraturan Daerah (Perda) Provinsi DIY Nomor 4 Tahun 2012 tentang Perlindungan dan Pemenuhan Hak-Hak Penyandang Disabilitas.

Priscyllia, F. 2016. Kajian Hukum Terhadap Fasilitas Pelayanan Publik Bagi Penyandang Disabilitas. LEX CRIMEN 5(3).

Purwanta, 2004. Pokok-Pokok Pikiran Dr. Mansour Fakih Refleksi Kawan Seperjuangan. Yogyakarta: SIGAB \& OXFAM Great Britain.

OHANA. 2007 . Perjanjian Internasional tentang Hak-Hak Penyandang Disabilitas 
Republik Indonesia, 2016, Undang-Undang No. 8 tahun 2016 Tentang Penyandang Disabilitas. Jakarta: Sekretaris Negara.

Setyaningsih, Wiwik. 2005. Perwujudan Elemen Aksesibilitas pada Bangunan Gedung dan Lingkungan, Unit Kajian Aksesibilitas Arsitektur (UKAA) UNS - 2005 : Policy And Regulation SEMINAR INTERNATIONAL Supporting Inclusion In Indonesia. Paper.

Windrawan, Puguh. 2015. Aksesibilitas Peradilan Bagi Penyandang Disabilitas. PUSHAM UII.

Zakariyah, Ummi, Husein, Rahmawati, 2016. PARIWISATA RAMAH PENYANDANG DISABILITAS Studi Ketersediaan Fasilitas Dan Aksesibilitas Pariwisata Untuk Disabilitas Di Kota Yogyakarta. Jurnal.

Wijoyono, Elan, Seberapa Ramah Ruang Publik Yogyakarta bagi Kelompok Rentan?,https://elantowow.wordpress.com/2016/01/04/seberapa-ramah-ruangpublik-yogyakarta-bagi-kelompok-rentan/. Diakses tanggal 3 September 2017 